\title{
Relationship between Mode of Delivery and Frequency and Treatment Outcomes of Congenital Nasolacrimal Dacryostenosis
}

\author{
Doğum Şeklinin Konjenital Nazolakrimal Dakriostenoz Görülme Sıklığı ve Tedavi \\ Sonuçları ile İlişkisi
}

\author{
(D) Fatma Esin Özdemir1, (D) Fadime Nuhoğlu², (D) Rumil Babayev² \\ ${ }^{1}$ Kanuni Sultan Süleyman Training and Research Hospital, Health Practice and Research Center, Clinic of Ophthalmology, İstanbul, Turkey
}

2Bezmialem Vakıf University Faculty of Medicine, Department of Ophthalmology, İstanbul, Turkey

\begin{abstract}
Introduction: The present study evaluates the relationship between the mode of delivery and the frequency and treatment outcomes of congenital nasolacrimal duct obstruction (CNDO).

Methods: The medical records of children who were referred to oculoplasty outpatient clinics due to epiphora and diagnosed with CNDO following ophthalmological examination were reviewed retrospectively. The patients' demographic characteristics, history of pregnancy and delivery, clinical characteristics of CNDO, and treatment outcomes were evaluated.

Results: The study included 167 eyes of 136 patients. The mode of delivery was vaginal in 61 patients (45\%) and cesarean section in 75 patients (55\%). The patients delivered by cesarean section were assigned to group 1, and those delivered via the vaginal route were assigned to group 2 . The mean age $(p=0.554)$, gender distribution $(p=0.661)$, laterality $(p=0.075)$ and mean birth weight $(p=0.918)$ did not differ significantly between the two groups. The success rate of probing did not differ significantly between the two groups $(p=0.146)$.

Conclusion: The present study found that the mode of delivery did not affect the frequency of CNDO in babies born at term, and there was also no significant difference in the success rate of probing between the two groups. Although the difference was not statistically significant, the authors found cesarean section to be associated with a higher risk of CNDO.
\end{abstract}

Keywords: Cesarean section, vaginal delivery, CNDO, probing, Hasner's valve $\ddot{0 Z Z}$

Amaç: Term bebeklerde doğum şeklinin konjenital nazolakrimal dakriostenoz (CNDO) görülme sıklığı ve tedavi sonuçları ile ilişkisini saptamaktır.

Yöntemler: Oküloplasti polikliniklerine epifora nedeniyle refere edilen ve oftalmolojik muayeneleri sonucunda CNDO tanısı alan çocukların tıbbi kayıtları retrospektif olarak incelendi. Hasta demografisi, hamilelik, doğum öyküsü, CNDO'nun klinik özellikleri ve tedavi sonuçları değerlendirildi.

Bulgular: Çalıșmaya 136 hastanın 167 gözü dahil edildi. Olguların \%55’i (75) kı, \%45’i (61) erkek idi. Olguların yașları 1-3 (ortalama: 1,8 yaş) idi. Olguların 61'i (\%45) vaginal yolla, 75’i (\%55) sezaryenle dünyaya gelmiști. Sezaryenle doğanlar birinci grup, vajinal yolla doğanlar da ikinci grup olarak değerlendirildi. Vaginal doğum ve sezaryen doğum gruplarının yaș ortalamaları $(p=0,554)$, cinsiyet dağılımları $(p=0,661)$, taraf dağılımları $(p=0,075)$, doğum ağırlığı $(p=0,918)$ ortalamaları arasında istatistiksel olarak anlamlı farklılık gözlenmemiştir. Vajinal doğum ve sezaryen doğum gruplarının probing başarı dağılımları arasında da istatistiksel olarak anlamlı farklılık gözlenmemiștir ( $p=0,146)$.

Sonuç: Bu çalıșmada doğum șeklinin term bebeklerde CNDO sıklığını değiștirmediğini saptadık. Vajinal doğum ve sezaryen doğum gruplarının probing başarı dağılımları arasında da istatistiksel olarak anlamlı bir farklılık gözlenmemiștir. Ancak istatistik olarak anlamlılık oluşturmasa da sezaryen doğumun daha fazla risk olușturduğunu saptadık.

Anahtar Kelimeler: Sezaryen doğum, vajinal doğum, CNDO, probing, Hasner valvi 


\section{Introduction}

Congenital nasolacrimal duct obstruction (CNDO) is the most common ocular disorder in the pediatric population, with a reported prevalence of approximately $20 \%$. The condition is caused by a failure in the drainage system of the nasolacrimal duct. A persistent membrane at Hasner's valve is the most common etiologic factor related to the development of CNDO. The condition often becomes symptomatic a few weeks after birth, and epiphora is the most common presenting symptom, although matting of the eyelashes, swelling of the lacrimal sac, and discharge from the lacrimal punctum upon the application of pressure on the lacrimal sac can also be observed (1-3).

First-line therapy includes massaging the lacrimal sac [Crigler (4) massage] and administering antibacterial drops to avoid bacterial superinfections. It is reported that $90 \%$ of CNDOs resolve spontaneously in the first year of life without requiring surgical intervention. Other treatment options include probing, silicone intubation, balloon dacryoplasty, and dacryocystorhinostomy (DCR) in patients who fail to respond to massage therapy. Most surgeons follow a conservative approach, involving massage, and topical therapy in the first year of life. Probing is the first-line therapy in epiphora that persists beyond the first year of life, followed by silicone intubation and balloon DCR after failed probing, whereas DCR is reserved as the last option for cases in which all other treatment options have failed $(5,6)$.

The nasolacrimal duct starts to develop during the fifth week of embryogenesis. CNDO occurs as a result of a canalization fault in the columnar epithelial cells that form the nasolacrimal duct. Canalization of the nasolacrimal duct normally takes place at the end of the sixth month of intrauterine life, although it may be delayed for several weeks after birth $(7,8)$. In a retrospective case series involving facial imaging of normal children, a 4.6-fold increase was noted in nasolacrimal duct volume during the first 34 months of life, and this volume expansion is associated with the increased intracanal hydrostatic pressure necessary to open the distal canal. For this reason, the incidence of CNDO is believed to be higher in premature infants than in term infants. The incidence of cesarean section (CS) is higher in premature infants than in term infants, and although there are many studies in the literature investigating the effect of the mode of delivery on the development of CNDO in premature and term infants, there have been few similar studies to date in term infants $(2,9,10)$.

The World Health Organization (WHO) recommends that the rate of CS should not exceed 15\%, taking countries with a low perinatal mortality rate in 1985 as a reference, although the WHO reported CS rates of 30.2\% in the United States, 22\% in the United Kingdom, 37.4\% in Italy, and 41.3\% in Brazil in 2010. The CS rate in Turkey was 6.9\% in 1993 but had increased to $51.2 \%$ by 2017 , and this upward trend in the prevalence rate elevated Turkey to one of the highest CS rates (11-13).

Due to this rapid increase in the popularity of $\mathrm{CS}$, even in infants born at term, the present study investigates the effect of the mode of delivery on the development of CNDO in term infants.

\section{Methods}

This retrospective study was conducted in accordance with the principles of the Declaration of Helsinki, and approval for the study was granted by the Bezmialem Vakıf University Non-Invasive Clinical Research Ethics Committee (approval number: 06/83, date: 19.03.2019). All patients provided written informed consent for their participation.

The medical records of patients who were referred to oculoplasty outpatient clinics due to epiphora, were diagnosed with CNDO after examination, had not undergone surgery previously, and were to undergo probing for the first time were reviewed retrospectively. Included in the study were patients diagnosed with CMDO after 12 months of age, those born after 36 weeks of gestation (term), those who underwent probing after 12 months of age, and those followed up for longer than 6 months.

Infants with a history of maternal drug use, infections, and X-ray exposure during pregnancy; those with a history of complicated vaginal delivery; those with a past history of trauma; those with anatomical abnormalities in the nasolacrimal duct; those born before 36 weeks of gestation; those who underwent surgery before the age of 12 month; and those with a patent nasolacrimal duct, as evidenced by duct lavage prior to surgery (functional epiphora), were excluded from the study.

The demographic characteristics of the patients, mode of delivery, gestational age, birth weight, age at presentation, mode of therapy, efficacy of therapy, and recurrences were all evaluated.

Diagnosis was based on history, an ophthalmological examination, and a fluorescein dye disappearance test (FDT) (14). The ophthalmological examination was performed to rule out ocular allergy, glaucoma, conjunctivitis, and eyelid anomalies (entropion, trichiasis, etc). For the FDT, a proparacaine $\mathrm{HCl}$ drop was dripped onto fluorescein paper and applied bilaterally to the patient's inferior fornix. The level of fluorescein on the lower eyelid was checked five minutes later and graded.

0 : No fluorescence in the conjunctival sac,

1: Thin fluorescing marginal tear strip persists,

2: More fluorescein persists, between 1 and 3,

3: Wide, brightly fluorescing tear strip.

Those who scored 2 or 3 in the fluorescein disappearance test were diagnosed with CNDO, and surgery was planned. All of the patients also underwent an otorhinolaryngological examination, and those identified with allergic rhinitis were first treated in the otorhinolaryngology clinic.

All surgeries were performed under general anesthesia. The patients first underwent lacrimal irrigation with a fluid lavage of rifampicin and saline (rifampicin diluted with saline at a ratio of 1:3). The patients found to have a patent duct during lacrimal irrigation were considered to have functional dacryostenosis. The superior and inferior lacrimal puncta were dilated before the probing procedure, after which the probe was advanced vertically until the ampulla, and then at an angle of $90^{\circ}$ to the horizontal plane. The probe was advanced up to the nasal wall of the lacrimal sac (until the bone was reached) and then directed $90^{\circ}$ downward until the membrane was felt to rupture. The same procedure was performed through the inferior punctum. Lavage fluid prepared with rifampicin [1 $\mathrm{mL}$ rifampicin, $125 \mathrm{mg} / 3 \mathrm{~mL}$ (the toxic dose of rifampicin in children is $600 \mathrm{mg}$ )] was administered into the nasolacrimal system to check for patency, and the fluid was aspirated 
from the nasal cavity. The procedure was considered to be successful upon observation of discharge of the rifampicin solution. The lacrimal system was then irrigated with a dexamethasone solution, and topical antibiotics (tobramycin four times daily), a fluorometholone steroid (four times daily) for two postoperative weeks and a nasal xylometazoline spray (twice daily) were applied.

The patients attended control visits on postoperative day 1 , at week 1 , week 2 , month 1 , and months 3 , and then every 3 months thereafter. Complaints of epiphora were questioned during the control visits, and a fluorescein disappearance test was performed. Cases without epiphora and those that scored 0 or 1 points on the fluorescein disappearance test were considered successful. Intraoperative and postoperative complications were evaluated. Patients in whom probing failed underwent repetitive probing 2 months later, and silicone intubation was performed in the same session. Those in whom silicon tube intubation failed were scheduled for external DCR.

The patients were divided into two groups on the basis of their mode of delivery, as group 1 (CS) and group 2 (vaginal delivery). The two groups were compared with respect to the prevalence of CNDO, gender, birth weight, gestational age at birth, and probing success.

\section{Statistical Analysis}

The Number Cruncher Statistical System 2007 Statistical Software (Utah, USA) was used for data analysis. Aside from the application of descriptive statistics (mean, standard deviation), a Shapiro-Wilk normality test was conducted to evaluate the distribution of variables, and an independentsamples t-test was used for paired comparisons of normally distributed variables. Univariate and multivariate logistic regression analyses were used to identify the factors affected by the mode of delivery. The level of significance was $\alpha=0.05$.

\section{Results}

The study included 167 eyes of 136 patients, of which 75 (55\%) were female and 61 (45\%) were male, with a mean age of 1.8 years (range: $1-3$ years). The mode of delivery was vaginal in 61 patients (45\%) and CS in 75 patients (55\%). Those delivered by CS were assigned to group 1 , and those delivered via the vaginal route were assigned to group 2. Mean age $(p=0.554)$, gender distribution $(p=0.661)$, laterality $(p=0.075)$, and mean birth weight $(p=0.918)$ did not differ significantly between the two groups. The mean gestational age at birth was significantly higher in group 1 than in group $2(p=0.007)$. The probing success rate not differ significantly between the two groups $(p=0.146)$ (Table 1). Age, gender, laterality, gestational age at birth, birth weight, and mode of delivery were found to be significantly insignificant in a univariate logistic regression analysis ( $p>0.05)$. The risk of failure was 2.09 times higher (0.76-3.74) in group 1 than in group 2. The probing success was significantly higher in those with a high gestational age $(p=0.096)$.

Recurrence occurred in six patients (8\%) in group 2 following the first probing attempt, and these patients underwent a repeat probing and silicone intubation 2 months later. Recurrence occurred in one patient after a mean follow-up of 7.1 months following silicone tube intubation, and this patient was then scheduled for external DCR. Recurrence occurred in 14 patients (15) after CS, and of these, 12 underwent repeat probing and silicone tube intubation, while two patients rejected therapy and were lost to follow-up. Recurrence occurred in 3 out 12 patients during a mean follow-up of 6.3 months, and these three patients were scheduled for external DSR. The epiphora resolved after external DSR.

\section{Discussion}

There is a limited body of knowledge regarding the etiopathogenesis of CNDO, although there have been many studies to date investigating treatment methods. Among these, there have been studies investigating the relationship between the development of CNDO and maternal age, maternal X-ray exposure, drug use during pregnancy, geographic and environmental characteristics, smoking status, parental education level, and gender of the infant, although no such relationships have been identified (15).

The marked increase in the prevalence of CS in recent years has prompted researchers to investigate the positive and negative effects of this mode of delivery on both the mother and the infant (16). As a common ocular disorder in newborns in ophthalmology outpatient clinics, the possible relationship between CNDO and the mode of delivery has attracted the attention of ophthalmologists and has prompted investigations into the effect of vaginal and CS deliveries on the nasolacrimal duct.

The uterine contractions required for the successful advancement of the infant along the birth canal during a vaginal delivery increases intrauterine hydrostatic pressure, which has been measured as high

\begin{tabular}{|c|c|c|c|c|c|c|}
\hline & & \multicolumn{2}{|c|}{ Vaginal delivery $(n=75)$} & \multicolumn{2}{|c|}{ Cesarean Section $(n=91)$} & $\mathbf{p}$ \\
\hline \multicolumn{2}{|l|}{ Age (months) } & \multicolumn{2}{|c|}{$19.59 \pm 10.18$} & \multicolumn{2}{|c|}{$20.51 \pm 9.75$} & $0.554 *$ \\
\hline \multirow{2}{*}{ Gender } & Girl & 38 & $50.67 \%$ & 43 & $47.25 \%$ & \multirow{2}{*}{$0.661+$} \\
\hline & Male & 37 & $49.33 \%$ & 48 & $52.75 \%$ & \\
\hline \multirow{2}{*}{ Side } & Left & 30 & $40.00 \%$ & 49 & $53.85 \%$ & \multirow{2}{*}{$0.075+$} \\
\hline & Right & 45 & $60.00 \%$ & 42 & $46.15 \%$ & \\
\hline \multicolumn{2}{|l|}{ Week of birth } & \multicolumn{2}{|c|}{$38.27 \pm 1.93$} & \multicolumn{2}{|c|}{$38.99 \pm 1.45$} & $0.007 *$ \\
\hline \multicolumn{2}{|l|}{ Birth weight } & \multicolumn{2}{|c|}{$3212.13 \pm 490.39$} & \multicolumn{2}{|c|}{$3204.84 \pm 420.46$} & $0.918 *$ \\
\hline \multirow{2}{*}{ Probing success } & Successful & 69 & $92.00 \%$ & 77 & $84.62 \%$ & \multirow{2}{*}{$0.146+$} \\
\hline & Unsuccessful & 6 & $8.00 \%$ & 14 & $15.38 \%$ & \\
\hline
\end{tabular}


as $100 \mathrm{mmHg}$. While some studies suggest that increased intrauterine pressure may lead to complications in the infant, others report that such pressure may act to open the nasolacrimal duct, particularly Hasner's valve, in the infant. It is reported that various collagenolytic enzymes are released from the uterus into the amniotic fluid due to uterine contractions during vaginal delivery, and this fluid is mostly directed into the nasolacrimal duct during a vaginal delivery. The increased activity of collagenolytic enzymes in amniotic fluid may cause early lysis of Hasner's valve and perforation of the membrane. It has been further reported that levels of collagenolytic enzymes are lower in the amniotic fluid in CS deliveries than in vaginal deliveries (17-20).

Studies in the literature have also reported an increased incidence of autoimmune and allergic disorders in recent years, in parallel to the increased rate of CS deliveries $(21,22)$. The authors of the present study suggest that this increase may be associated with increased inflammation in the lacrimal duct, which may prevent opening of the nasolacrimal duct, thus negatively affecting probing success.

In 2015, Zhang et al. (23) reported an expansion in the bony part of the nasolacrimal duct on the obstructed side in patients with CNDO, and a significant expansion of the affected bony nasolacrimal duct areas with transverse and vertical diameters has been demonstrated on the computed tomography (CT) scans of patients with unilateral CNDO, when compared with the unaffected side. The bony part of the lacrimal duct is soft in childhood, and the increased pressure resulting from a blockage of the nasolacrimal duct may lead to enlargement of the intraosseous portion of the ipsilateral lasolacrimal duct. This is caused by the constant increase in hydrostatic pressure within the lacrimal duct that occurs with age, and this may play a role in the recovery of the blockage with advancing age $(2,23)$. In practice, CT scans are not routinely requested in patients with CNDO in the ophthalmology clinic, although eight patients in the present study underwent a CT scan for various reasons, and a review of these CT scans revealed an expanded nasolacrimal duct on the affected side when compared with that of the contralateral duct. Probing was performed after 12 months of age in all patients in the present study in an attempt to open the nasolacrimal duct naturally.

In a study by Tavakoli et al. (24) involving 106 patients, a significantly higher percentage of patients with CNDO (61\%) were delivered via CS $(p=0.0001)$. Among full-term infants, there was a $55 \%$ greater risk [odds ratio (OR): 5 1.55; 95\% confidence interval $(\mathrm{Cl}), 0.98-2.43 ; \mathrm{p}=0.067]$ of CNDO in those born by CS, when compared with other babies. Among preterm babies, there was no significantly greater likelihood of CNLDO in those born by CS when compared with those born vaginally ( $p=0.575$ ). CNDO did not resolve spontaneously in 50 patients, including the 37 patients delivered by CS (74\%) and the 13 patients delivered via the vaginal route $(26 \%)(p=0.007)$. Among the patients in whom first-line probing failed, $86.2 \%$ were born via CS and $13.8 \%$ via the vaginal route (24).

Spaniol et al. (25) also reported no statistically significant association between the overall CS rate and incidence of CNDO, although primary CS was significantly more frequent among patients with CNDO (73.15\%, $p<0.05)$. The difference was significant in both genders for the 2000-
2008 period $(p<0.05 \%)$. The relative risk for CNLDO was 17 -fold higher in children delivered by primary CS (25).

In a study by Dolar Bilge (26) conducted in Turkey, the gestational age of babies who were born via CS was lower than that of babies who born via spontaneous vaginal delivery (NSVD; $p=0.002$ ). Babies born via CS were found to be at a 3.75-fold greater risk of developing CNLDO, when compared with those born via the vaginal route (OR: 3.754) (26).

Palo et al. (27) reported no significant relationship between CNDO and the mode of delivery but reported complex CNDOs to be more frequent in CS deliveries.

The present study found the mode of delivery to have no effect on the frequency of CNDO in babies born at term. CNDO was noted to be more common in infants with a low birth weight, and the success rate of probing was higher in patients delivered via the vaginal route.

\section{Study Limitations}

As a limitation of the present study, the study group comprised only patients who were referred to oculoplasty outpatient clinics with a diagnosis of CNDO for surgical treatment. As such, no patients with spontaneously resolved CNDO or with resolved CNDO after massage therapy were included in the study.

\section{Conclusion}

The present study found that the mode of delivery did not affect the frequency of CNDO in babies born at term, and there was also no significant difference in the success rate of probing between the two groups. Although the difference was statistically insignificant, the authors found CS to be associated with a higher risk of CNDO. We believe that a wider range of studies including these groups is needed.

Ethics Committee Approval: This retrospective study was conducted in accordance with the principles of the Declaration of Helsinki, and approval for the study was granted by the Bezmialem Vakıf University Non-Invasive Clinical Research Ethics Committee (approval number: 06/83, date: 19.03.2019).

Informed Consent: All patients provided written informed consent for their participation.

Peer-review: Externally peer-reviewed.

Authorship Contributions: Surgical and Medical Practices - F.E.Ö., F.N.; Concept - F.E.Ö., R.B.; Design - F.E.Ö., F.N.; Data Collection or Processing - F.E.Ö., R.B.; Analysis or Interpretation - F.E.Ö., F.N.; Literature Search F.E.Ö., R.B.; Writing - F.E.Ö.

Conflict of Interest: No conflict of interest was declared by the authors.

Financial Disclosure: The authors declared that this study received no financial support.

\section{References}

1. MacEwen CJ, Young JD. Epiphora during the first year of life. Eye 1991; 5: 596-600.

2. Moscato EE, Kelly JP, Weiss A. Developmental anatomy of the nasolacrimal duct: implications for congenital obstruction. Ophthalmology 2010; 117: 2430-4. 
3. Paul TO, Shepherd R. Congenital nasolacrimal duct obstruction: natural history and the timing of optimal intervention. J Pediatr Ophthalmol Strabismus 1994; 31: 362-7.

4. Crigler LW. The treatment of congenital dacryocystitis. JAMA 1923; 81: 23-4.

5. Takahashi Y, Kakizaki H, Chan WO, Selva D. Management of congenital nasolacrimal duct obstruction. Acta Ophthalmol (Copenh) 2010; 88: 506-13.

6. Prokosch V, Busse H, Thanos S, Eter N, Stupp T. [Impact of age on success rate of lacrimal duct irrigation with silicone tube intubation in connatal lacrimal duct stenosis]. Klin Monabl Augenheilkd 2013; 230: 1020-4.

7. Wang JC, Cunningham MJ. Congenital dacryocystocele: is there a familial predisposition?. Int J Pediatr Otorhinolaryngol 2011; 75: 430-2.

8. Congenital lacrimal abnormalities. In: Bosniak SL (ed.) Principles and practice of ophthalmic plastic and reconstructive surgery, vol. 2. Philadelphia, PA: W. B. Saunders Company; 1996, pp. 731-47.

9. Lorena SH, Silva JA, Scarpi MJ. Congenital nasolacrimal duct obstruction in premature children. J Pediatr Ophthalmol Strabismus 2013; 50: 239-44.

10. Racusin DA, Antony KM, Haase J, Bondy M, Aagaard KM. Mode of Delivery in Premature Neonates: Does It Matter? AJP Rep 2016; 6: e251-9.

11. WHO Robson Classification Implementation Manual: World Health Organization. Robson classification: implementation manual. World Health Organization. License: CC BY-NC-SA 3.0 IGO; 2017. Available from: https:// apps.who.nt/iris/handle/10665/259512 .

12. World Health Organization. WHO statement on caesarean section rates. Geneva: World Health Organization; 2015. (WHO/RHR/15.02). Available from: http://www.who.int/reproductivehealth/publications/maternalperinatal_ health/cs-statement/en/

13. Hacettepe University Institute of Population Studies 2009. Turkey Demographic and Health Survey Main Report. http://wwwhipshacettepeedutr/tnsa2008/ data/TNSA-2008_ana_Raportrpdf

14. MacEwen CJ, Young JD. The fluorescein disappearance test (FDT): an evaluation of its use in infants. J Pediatr Ophthalmol Strabismus 1991; 28: 302-5.

15. Noda S, Hayasaka S, Setogawa T. Congenital nasolacrimal duct obstruction in Japanese infants: its incidence and treatment with massage. J Pediatr Ophthalmol Strabismus 1991; 28: 20-2.
16. Magnus MC, Håberg SE, Stigum H, Nafstad P, London SJ, Vangen S, Nystad W. Delivery by Cesarean section and early childhood respiratory symptoms and disorders: the Norwegian mother and child cohort study. Am J Epidemiol 2011: 174: 1275-85.

17. Bhattacharjee A, Uddin S, Purkaystha P. Deviated nasal septum in the newborn-A 1-year study. Indian J Otolaryngol Head Neck Surg 2005; 57: 304-8.

18. Gray LP. Septal and associated cranial birth deformities: types, incidence and treatment. Med J Aust 1974; 1: 557-63.

19. Wolfs GM, van Leeuwen M. Electromyographic observations on the human uterus during labour. Acta Obstet Gynecol Scand Suppl 1979; 90: 1-61.

20. Helmig R, Oxlund H, Petersen LK, Uldbjerg N. Different biomechanical properties of human fetal membranes obtained before and after delivery. Eur J Obstet Gynecol Reprod Biol 1993; 48: 183-9.

21. Bonifacio E, Warncke K, Winkler C, Wallner M, Ziegler AG. Cesarean section and interferon-induced helicase gene polymorphisms combine to increase childhood type 1 diabetes risk. Diabetes 2011; 60: 3300-6.

22. Magnus MC, Håberg SE, Stigum H, Nafstad P, London SJ, Vangen S, et al. Delivery by Cesarean section and early childhood respiratory symptoms and disorders: the Norwegian mother and child cohort study. Am J Epidemiol 2011; 174: 1275-85.

23. Zhang $\mathrm{C}, \mathrm{Wu} \mathrm{Q}$, Cui $\mathrm{Y}, \mathrm{Yu} \mathrm{G}$. Anatomy of nasolacrimal canal in congenital nasolacrimal duct obstruction - 18 cases retrospective study. Acta Ophthalmol 2015; 93: e404-5.

24. Tavakoli M, Osigian CJ, Saksiriwutto P, Reyes-Capo DP, Choi CJ, Vanner EA, et al. Association between congenital nasolacrimal duct obstruction and mode of delivery at birth. J AAPOS 2018; 22: 381-5.

25. Spaniol K, Stupp T, Melcher C, Beheiri N, Eter N, Prokosch V. Association between congenital nasolacrimal duct obstruction and delivery by cesarean section. Am J Perinatol 2015; 32: 271-6.

26. Dolar Bilge A. Mode of delivery, birth weight and the incidence of congenital nasolacrimal duct obstruction. Int J Ophthalmol 2019; 12: 1134-8.

27. Palo M, Gupta S, Naik MN, Ali MJ. Congenital Nasolacrimal Duct Obstruction and Its Association With the Mode of Birth. J Pediatr Ophthalmol Strabismus 2018; 55: 266-8. 